\title{
Stripping Voltammetric Methods for Determination of the Antiparasitic Drug Nitazoxanide in Bulk Form, Pharmaceutical Formulation and Human Serum
}

\author{
Hanaa S. El-Desoky,* Mohamed M. Ghoneim and Mohamed M. Abdel-Galeil \\ Analytical and Electrochemistry Research Unit, Chemistry Department, Faculty of Science, \\ Tanta University, 31527 Tanta, Egypt
}

\begin{abstract}
Voltamogramas cíclicos de nitazoxanida medidos no eletrodo de gota de mercúrio no tampão universal Britton-Robinson com valores de $\mathrm{pH}$ de 2 a 11 contendo $20 \%$ (v/v) de etanol exibiram um único pico catódico irreversível de 4-elétrons, correspondendo à redução de seu grupo $\mathrm{NO}_{2}$ para hidroxilamina. Observou-se que a nitazoxanida adsorve na superfície do eletrodo de mercúrio numa monocamada com cobertura superficial de $3,16 \times 10^{-10} \mathrm{~mol} \mathrm{~cm}^{-2}$ na qual cada molécula adsorvida ocupa uma área de $0.525 \mathrm{~nm}^{2}$. Baseado no seu comportamento de adsorção na superfície do eletrodo de mercúrio, métodos voltamétricos validados 'stripping' catódico adsortivo com varredura linear (VL), pulso diferencial (PD) e onda quadrada (OQ) foram descritos para determinação de nitazoxanida no seio da solução. Limites de deteção de $1,5 \times 10^{-10}, 2,4 \times 10^{-10}$ e $3,0 \times 10^{-11} \mathrm{~mol} \mathrm{~L}^{-1} \mathrm{e}$ limites de quantificação de nitazoxanida de $5,0 \times 10^{-10}, 8,0 \times 10^{-10} \mathrm{e} 1,0 \times 10^{-10} \mathrm{~mol} \mathrm{~L}^{-1}$ no seio da solução foram obtidos a partir dos métodos VVL, VPD e VOQ descritos acima, respectivamente. Os métodos descritos foram aplicados com sucesso para a determinação de nitazoxanida em sua formulação farmacêutica (pó de Cryptonaz) e em serum humano sem a necessidade de pré-tratramento da amostra, etapas de extração ou a formação de cromógenos coloridos antes da análise. Além disto, determinou-se nitazoxanida com sucesso e sem interferência de produtos de degradação induzidos por ácido ou base, indicando a estabilidade e poder dos métodos voltamétricos descritos.
\end{abstract}

Cyclic voltammograms of nitazoxanide recorded at the hanging mercury drop electrode in the Britton-Robinson universal buffer of $\mathrm{pH}$ values 2 to 11 containing $20 \%$ (v/v) ethanol exhibited a single 4-electron irreversible cathodic peak corresponding to the reduction of its $\mathrm{NO}_{2}$ group to the hydroxylamine stage. Nitazoxanide was found to adsorb onto surface of the mercury electrode in a monolayer surface coverage of $3.16 \times 10^{-10} \mathrm{~mol} \mathrm{~cm}^{-2}$ in which each adsorbed molecule occupies an area of $0.525 \mathrm{~nm}^{2}$. Based on its adsorption behavior onto the mercury electrode surface, validated linear sweep (LS), differential pulse (DP) and square wave (SW) adsorptive cathodic stripping voltammetric methods were described for determination of bulk nitazoxanide. Limits of detection of $1.5 \times 10^{-10}, 2.4 \times 10^{-10}$ and $3.0 \times 10^{-11} \mathrm{~mol} \mathrm{~L}^{-1}$ and limits of quantification of $5.0 \times 10^{-10}, 8.0 \times 10^{-10}$ and $1.0 \times 10^{-10} \mathrm{~mol} \mathrm{~L}^{-1}$ nitazoxanide in the bulk form were achieved by means of the described LS, DP and SW adsorptive cathodic stripping voltammetric methods, respectively. The described methods were successfully applied for determination of nitazoxanide in its pharmaceutical formulation (Cryptonaz powder) and in spiked human serum without the necessity for sample pretreatment, time consuming extraction steps or formation of colored chromogens prior to the analysis. Besides, nitazoxanide was successfully determined without interference from its acid or base-induced degradation products indicating the stability-indicating power of the described voltammetric methods.

Keywords: nitazoxanide, cryptonaz powder, human serum, degradation, determination, stripping voltammetry

\section{Introduction}

Nitazoxanide [2-(5-nitro-1,3-thiazol-2-ylcarbamoyl) phenyl acetate] (Scheme A) has a broad-spectrum

*e-mail: hseldesoky@hotmail.com activity against numerous intestinal protozoa, helminths and anaerobic bacteria. Nitazoxanide is prescribed for treatment of diseases caused by Giardia intestinalis and Cryptosporidium in immune-compromised patients, including those with AIDS or HIV infection. The drug represents a significant advance in the treatment of intestinal parasitical infections worldwide. ${ }^{1-3}$ 


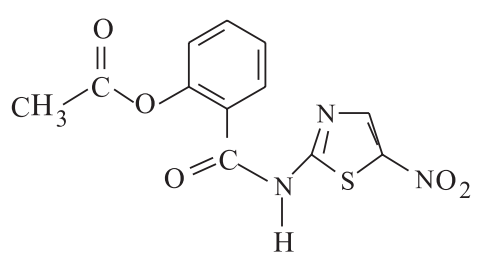

Scheme A. Chemical structure of nitazoxanide.

No official method for determination of nitazoxanide in pharmaceutical formulation and/or biological fluids is available yet in British or US pharmacopoeia. Chromatographic ${ }^{4-10}$ and spectrophotometric ${ }^{11-13}$ analytical methods have been reported for determination of nitazoxanide in the bulk form as well as in pharmaceutical formulations. The reported chromatographic methods $\mathrm{s}^{4-10}$ necessitate sample pretreatment and time-consuming extraction steps prior to analysis of the drug. Moreover, these methods require expensive equipment and considerable skills are necessary to operate them successfully. On the other hand, the reported spectrophotometric methods ${ }^{11-13}$ require time-consuming reduction and oxidation steps for formation of colored chromogens prior to the analysis. A simple and sensitive procedure is desired for determination of nitazoxanide and testing content uniformity of its dosage form. Stripping voltammetry is an extremely sensitive electrochemical technique that utilizes a nonelectrolytic preconcentration (accumulation) step for trace determination of a wide range of drugs in different matrices. Preconcentration (accumulation) of the analyte can be viewed as an effective extraction step in which its species are accumulated onto surface of the working electrode to a much higher level than they exist in sample solution. The combination of a preconcentration step with the advanced voltammetric measurement generates the extremely favorable signal-to-background ratio that characterizes stripping voltammetric analysis. ${ }^{14}$

To date no electroanalytical method has been reported in the literature for determination of nitazoxanide. So, the present work aimed to describe validated simple, fast and precise stability indicating adsorptive cathodic stripping voltammetric methods for trace determination of nitazoxanide in the bulk form, pharmaceutical formulation and in human serum without sample pretreatment, extraction or formation of colored chromogens prior to the analysis.

\section{Experimental}

\section{Materials and solutions}

(a) Nitazoxanide was kindly provided by Alkan Pharma for Copadpharma (Cairo, Egypt) and was used without further purification. The pharmaceutical formulation "Cryptonaz powder" (Alkan Pharma for Copadpharma, Cairo, Egypt) claimed to contain $80 \mathrm{mg}$ nitazoxanide per $1.0 \mathrm{~g}$ powder (which is used as an oral suspension of $100 \mathrm{mg}$ powder per $5 \mathrm{~mL}$ ) was purchased from the local market. A human serum sample was kindly provided by Tanta University Hospital (Tanta, Egypt), filtered through a $0.45 \mu \mathrm{m}$ milli-pore filter (Gelman, Germany) then kept frozen until use.

(b) A stock standard solution of bulk nitazoxanide $\left(1 \times 10^{-3} \mathrm{~mol} \mathrm{~L}^{-1}\right)$ was prepared in ethanol (Merck, Darmstadt, Germany) then stored at $4{ }^{\circ} \mathrm{C}$ until assay. Working solutions $\left(1 \times 10^{-7}\right.$ to $\left.1 \times 10^{-4} \mathrm{~mol} \mathrm{~L}^{-1}\right)$ bulk nitazoxanide were prepared daily by appropriate dilution of the standard solution of bulk nitazoxanide with ethanol just before use.

(c) For preparation of Cryptonaz solution, an amount of Cryptonaz powder equivalent to $1 \times 10^{-3} \mathrm{~mol} \mathrm{~L}^{-1}$ nitazoxanide was accurately transferred into a $100 \mathrm{~mL}$ calibrated flask containing $70 \mathrm{~mL}$ ethanol. The contents of the flask were sonicated for about $10 \mathrm{~min}$ and then filled up with ethanol. Afterwards, the solution was filtered through a $0.45 \mu \mathrm{m}$ Milli-pore filter (Gelman, Germany). Desired concentrations of nitazoxanide were obtained by accurate dilution of the prepared solution with ethanol. A digital micro-pipetter (Volac, John Poulten Ltd., Essex, UK) was used for transferring the solutions during measurements.

(d) Human serum samples ( $1.0 \mathrm{~mL}$ each) were fortified with various concentrations of nitazoxanide $\left(1 \times 10^{-7}\right.$ to $\left.1 \times 10^{-4} \mathrm{~mol} \mathrm{~L}^{-1}\right)$ in $3.0 \mathrm{~mL}$ volume polypropylene microcentrifuge tubes then each was mixed with a $1.0 \mathrm{~mL}$ volume ethanol to denature and precipitate proteins. After vortexing each tube for one minute the precipitated proteins were separated out by centrifugation (using an Eppendorf AG centrifuge 5417C, Hamburg, Germany) for $4 \mathrm{~min}$ at $14000 \mathrm{rpm}$. The clear supernatant layer in each tube was filtrated through a $0.45 \mu \mathrm{m}$ milli-pore filter (Gelman, Germany) to produce protein-free human serum solutions spiked with various concentrations $\left(1 \times 10^{-4}\right.$ to $\left.1 \times 10^{-7} \mathrm{~mol} \mathrm{~L}^{-1}\right)$ of nitazoxanide.

(e) A series of Britton-Robinson (B-R) universal buffer of $\mathrm{pH}$ values 2 to 11 was prepared and used as a supporting electrolyte. All the chemicals were of analytical grade and were used without further purification.

\section{Induced degradation studies}

(a) $10.0 \mathrm{~mL}$ of ethanolic solution of nitazoxanide $\left(2 \times 10^{-4} \mathrm{~mol} \mathrm{~L}^{-1}\right)$ were mixed with $10 \mathrm{~mL}$ of $4.0 \mathrm{~mol} \mathrm{~L}^{-1}$ $\mathrm{HCl}$ solution. The solution was then refluxed in a twonecked round-bottomed dark flask for $120 \mathrm{~min}$. At adequate time intervals a certain volume of the treated solution 
was withdrawn with micropipette to a $10.0 \mathrm{~mL}$ volume calibrated flask, immediately cooled in ice path to quench the acid hydrolysis reaction, and then filled up with a B-R universal buffer of $\mathrm{pH} 4$ to give a final concentration of $1 \times 10^{-7} \mathrm{~mol} \mathrm{~L}^{-1}(\mathrm{pH} 4$ was chosen for assay of the drug and was adjusted to the required optimum $\mathrm{pH}$ with $\mathrm{NaOH}$ solution). Concentration of the undegraded standard nitazoxanide after different time intervals of acid-induced degradation was determined by means of the described SW-AdCS voltammetric method.

(b) On the other hand, $10.0 \mathrm{~mL}$ of ethanolic solution of nitazoxanide $\left(2 \times 10^{-4} \mathrm{~mol} \mathrm{~L}^{-1}\right)$ was mixed with $10 \mathrm{~mL}$ of $1.0 \mathrm{~mol} \mathrm{~L}{ }^{-1} \mathrm{NaOH}$ solution at room temperature. At adequate time intervals a certain volume of the treated solution was withdrawn, introduced into a $10.0 \mathrm{~mL}$ volume calibrated flask, then diluted to volume with a B-R universal buffer of $\mathrm{pH} 4$ to give a final concentration of $1 \times 10^{-7} \mathrm{~mol} \mathrm{~L}^{-1}$ ( $\mathrm{pH}$ of the solution was adjusted to the required optimum $\mathrm{pH}$ with $\mathrm{HCl}$ solution).

\section{Instrumentations}

(a) Voltammetric measurements were carried out using computer-controlled Potentiostat / Galvanostat Models 263A and 273A-PAR (Princeton Applied Research, Oak Ridge, TN, USA) with the software 270/250-PAR. Electrode assemblies (303A-PAR) each incorporated with a threeelectrode micro-electrolysis cell comprising of a hanging mercury drop electrode (HMDE) of an area of $0.026 \mathrm{~cm}^{2}$, an $\mathrm{Ag} / \mathrm{AgCl} / \mathrm{KCl}_{\mathrm{s}}$ reference electrode and a platinum wire as a counter electrode were used in the measurements.

(b) A potentiostat / galvanostat (Model 173-PAR) incorporated with a digital coulometer (179-PAR) was used for controlled potential electrolysis. A micro-cell incorporated with a platinum wire sealed through the cell bottom for contact with a mercury pool cathode, a saturated calomel electrode as a reference electrode and a platinum gauze as a counter electrode was used. The potential selected was adjusted to be equal to the half peak potential $\left(\mathrm{E}_{\mathrm{p} / 2}\right)$ of cyclic voltammogram of the reactant plus $-0.1 \mathrm{~V}$. The total charge $(\mathrm{Q})$ passed during the exhaustive electrolysis of nitazoxanide in B-R universal buffers of various $\mathrm{pH}$ values (4, 7 and 9) was obtained by integrating the current electronically. Using Faraday's equation: $\mathrm{N}=\mathrm{Q} / \mathrm{nF}$ (where $\mathrm{N}$ is the number of moles of substance being electrolyzed) the total number of electrons (n) transferred per reactant molecule at the different $\mathrm{pH}$ values was estimated and was found to be four. These results indicated the reduction of the $\mathrm{NO}_{2}$ group of nitazoxanide molecule at various $\mathrm{pH}$ values to the hydroxylamine stage via the consumption of four electrons. (c) Electronic absorption spectra of nitazoxanide was recorded at room temperature within the wavelength range 200 to $600 \mathrm{~nm}$ using a Shimadzu UV-visible double-beam spectrophotometer Model 160A (Kyoto, Japan) with $1 \mathrm{~cm}$ matched quartz cell.

(d) A Mettler balance (Toledo-AB104, Greifensee, Switzerland) was used for weighing the solid materials used in the present study. A pH-meter (Crison, Barcelona, Spain) was used for measuring the $\mathrm{pH}$ values of the investigated solutions. The de-ionized water used in this work was obtained by a Purite-Still Plus de-ionizer connected to an AquaMatic double-distillation water system (Hamilton Laboratory Glass Ltd., Kent, UK).

\section{General Analytical Procedure}

$10.0 \mathrm{~mL}$ of the B-R universal buffer of $\mathrm{pH} 4$ containing the appropriate concentration of the analyte (bulk nitazoxanide, Cryptonaz powder or spiked human serum) were transferred into the micro-electrolysis cell and then deoxygenated with pure nitrogen gas before measurements while a stream of nitrogen gas was kept over surface of the solution in the electrolysis cell during the measurements. Preconcentration of the analyte onto surface of the HMDE was carried out by adsorptive accumulation at $-0.05 \mathrm{~V}$ (vs. $\mathrm{Ag} / \mathrm{AgCl} / \mathrm{KCl}_{\mathrm{s}}$ ) for $120 \mathrm{~s}$ while stirring the solution at $400 \mathrm{rpm}$. After elapsed the accumulation time, the stirrer was stopped and a $5 \mathrm{~s}$ rest period was allowed for the solution to become quiescent. Voltammograms were recorded by scanning the potential towards the negative direction using differential pulse, linear sweep or square wave potential-waveform. Quantification of nitazoxanide was performed by means of both calibration curve and standard addition methods.

\section{Results and Discussion}

\section{Cyclic voltammetric studies}

Cyclic voltammograms of $1 \times 10^{-4} \mathrm{~mol} \mathrm{~L}^{-1}$ nitazoxanide recorded at the HMDE in the B-R universal buffer of various $\mathrm{pH}$ values (2 to 11 ) containing $20 \%$ (v/v) ethanol displayed a well-defined single 4-electron irreversible cathodic peak, Figure 1, which was attributed to reduction of its $\mathrm{NO}_{2}$ group to the hydroxylamine stage ${ }^{15-17}$ as confirmed from controlled-potential coulometry measurements. The peak potential $\left(\mathrm{E}_{\mathrm{p}}\right)$ shifted to more negative values upon the increase of $\mathrm{pH}$ of the medium indicating the involvement of protons in the electrode reaction and that the proton-transfer reaction precedes the electron transfer. ${ }^{18} \mathrm{~A}$ linear relationship of the peak potential $\left(\mathrm{E}_{\mathrm{p}}\right) v s .(\mathrm{pH})$ of the medium following 


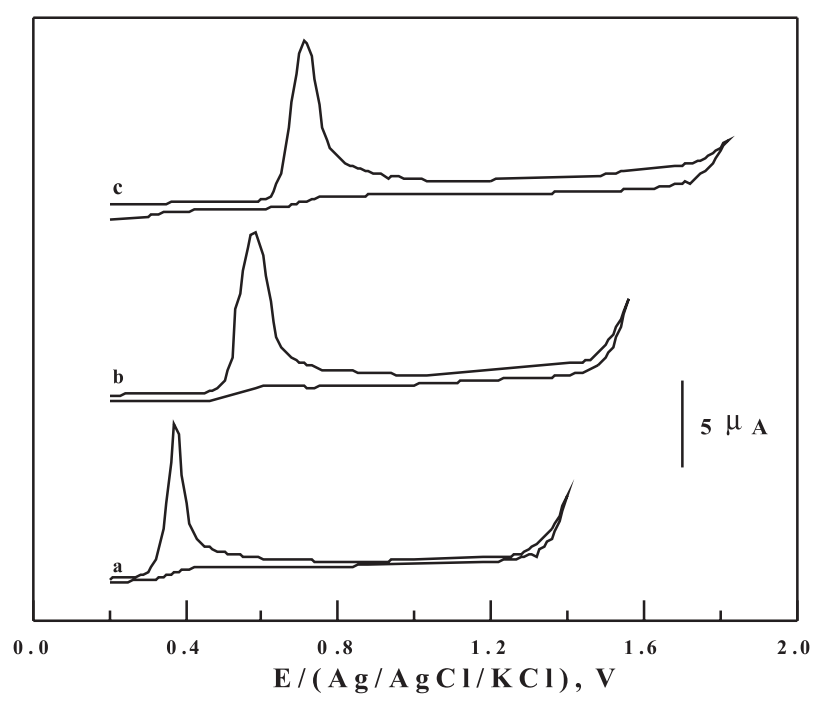

Figure 1. Cyclic volammograms of $1 \times 10^{-4} \mathrm{~mol} \mathrm{~L}^{-1}$ nitazoxanide at the HMDE in B-R universal buffers of pH values: 4 (a), 7 (b) and 9 (c) at a scan rate of $300 \mathrm{mV} \mathrm{s}^{-1}$.

the regression equation: $\mathrm{E}_{\mathrm{p}}(\mathrm{V})=0.068 \mathrm{pH}+0.104$, $(\mathrm{r}=0.997$ and $\mathrm{n}=7)$ was obtained. Its slope value equals $68 \mathrm{mV}=\left\{(59 / \alpha) .\left(\mathrm{m} / \mathrm{n}_{\mathrm{a}}\right)\right\}$, where $\mathrm{n}_{\mathrm{a}}$ and $\mathrm{m}$ are the numbers of electrons and protons involved in the rate determining step, respectively, and $\alpha$ is the symmetry transfer coefficient. It is well know that two electrons $\left(\mathrm{n}_{\mathrm{a}}=2\right)$ and one proton $(\mathrm{m}=1)$ are involved in the rate-determining step of the electro-reduction process of $\mathrm{NO}_{2}$ group, ${ }^{19}$ i.e., the ratio $\left(\mathrm{m} / \mathrm{n}_{\mathrm{a}}\right)=1 / 2$. Accordingly, $\alpha$ - value of 0.43 was estimated from slope value $(68 \mathrm{mV} / \mathrm{pH})$ of the $\left(\mathrm{E}_{\mathrm{p}}\right) v s$. $(\mathrm{pH})$ plot, indicating the irreversible nature of the electrode process of nitazoxanide at the mercury electrode. ${ }^{18}$

On the other hand, the peak potential $\left(\mathrm{E}_{\mathrm{p}}\right)$ shifted to more negative values with the increase of scan rate $v$ (25 to $300 \mathrm{mV} \mathrm{s}^{-1}$ ) indicating the irreversible nature of the electrode reaction. ${ }^{20,21}$ Linear relationships of peak potential $\left(\mathrm{E}_{\mathrm{p}}\right) v s$. logarithm of scan rate $(v)$ at different $\mathrm{pH}$ values ( $\mathrm{pH} 2$ to 11$)$ following the regression equation $\mathrm{E}_{\mathrm{p}}(\mathrm{V})=(0.068-0.074)$ $\log v+(0.32-0.76),(r=0.999 \pm 0.002$ and $n=5)$ were obtained. According to Nicholson and Greef, ${ }^{20,21}$ values of $\alpha n_{a}$ of 0.80 to 0.87 and $\alpha$ of 0.40 to 0.44 (for $n_{a}=2$ ) were estimated confirming again the totally irreversible nature of the electrode process of nitazoxanide at the HMDE.

The sharp cathodic peak of nitazoxanide obtained in the B-R universal buffer suggests its strong adsorption onto surface of the mercury electrode. Furthermore, adsorption of nitazoxanide onto the mercury surface was identified by recording cyclic voltammograms of $5 \times 10^{-7} \mathrm{~mol} \mathrm{~L}^{-1}$ nitazoxanide at a scan rate of $100 \mathrm{mV} \mathrm{s}^{-1}$ in the $\mathrm{B}-\mathrm{R}$ universal buffer of $\mathrm{pH} 4$ following its preconcentration onto the HMDE by adsorptive accumulation under open circuit conditions (Figure 2, scan a) then at an accumulation potential $\left(\mathrm{E}_{\mathrm{acc}}\right)$ of $-0.05 \mathrm{~V}\left(v s . \mathrm{Ag} / \mathrm{AgCl} / \mathrm{KCl}_{\mathrm{s}}\right)$ for $30 \mathrm{~s}$ (Figure 2, $1^{\text {st }}$ cycle $\mathrm{b}$ and $2^{\text {nd }}$ cycle $\mathrm{c}$ ). The more enhanced peak current magnitude of nitazoxanide following its preconcentration onto the HMDE (Figure 2, $1^{\text {st }}$ cycle b) indicated its adsorption onto the mercury electrode surface. Moreover, the logarithm of the peak current $\left(i_{p}\right) v s$. logarithm of scan rates $(v)\left(100\right.$ to $\left.500 \mathrm{mV} \mathrm{s}^{-1}\right)$ was a linear relationship following the regression equation: $\log i_{p}=0.94 \log v-1.33(r=0.999$ and $n=5)$. The slope value of 0.94 is very close to the expected theoretical value of 1.0 for an ideal reaction of surface species. ${ }^{22}$

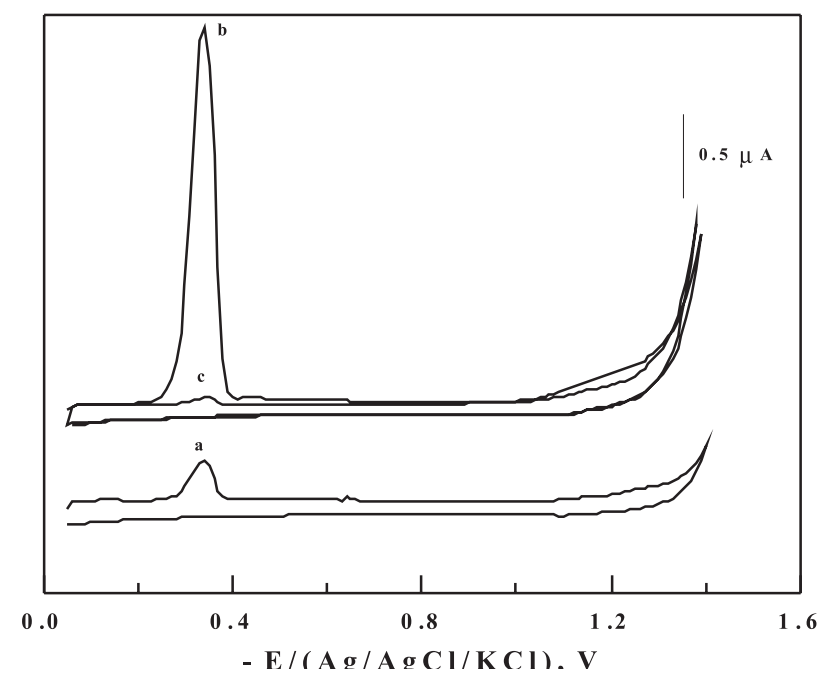

Figure 2. Cyclic voltammograms of $5 \times 10^{-7} \mathrm{~mol} \mathrm{~L}^{-1}$ nitazoxanide in the $\mathrm{B}-\mathrm{R}$ universal buffer of $\mathrm{pH} 4$ at a scan rate of $100 \mathrm{mV} \mathrm{s}^{-1}$ : following its preconcentration onto the HMDE by adsorptive accumulation at open circuit conditions (a) then at $-0.05 \mathrm{~V}$ for $30 \mathrm{~s}\left\{1^{\text {st }}\right.$ cycle (b) and $2^{\text {nd }}$ cycle (c)\}.

The electrode surface coverage of nitazoxanide $\Gamma^{\circ}$ (mol cm${ }^{-2}$ ) in a B-R universal buffer of $\mathrm{pH} 4$ was calculated using the relation: $\Gamma^{\circ}=\mathrm{Q} / \mathrm{nFA}$, where $\mathrm{Q}$ is the charge in $\mu \mathrm{C}$ related to the surface area under the cyclic voltammeric peak, $n$ is the total number of electrons consumed in the reduction process $(n=4), F$ is the Faraday constant and $A$ is the surface area of the working electrode $\left(0.026 \mathrm{~cm}^{2}\right)$. On dividing the amount of charge (Q) consumed by the surface process, $3.17 \mu \mathrm{C}$, by the conversion factor $\mathrm{nFA}$ $\left(10034.65 \times 10^{6} \mu \mathrm{C}\right)$, a monolayer surface coverage of $3.16 \times 10^{-10} \mathrm{~mol} \mathrm{\textrm {cm } ^ { - 2 }}$ was obtained. Each adsorbed nitazoxanide molecule thus occupied an area of $0.525 \mathrm{~nm}^{2}$.

\section{Stripping voltammetric studies}

Stripping voltammetric methods were optimized for trace determination of nitazoxanide applying linear sweep, differential pulse and square wave potential-waveforms. Stripping voltammograms of bulk nitazoxanide in the B-R 
universal buffer ( $\mathrm{pH} 2$ to 11) recorded by linear sweep, differential pulse, or square wave voltammetry following its preconcentration onto the HMDE by adsorptive accumulation for $30 \mathrm{~s}$ exhibited a well-defined single irreversible cathodic peak with a better enhanced peak current magnitude at $\mathrm{pH}$ 4. Therefore, a B-R universal buffer of $\mathrm{pH} 4$ was chosen as a supporting electrolyte in the rest of study.

\section{Linear sweep stripping voltammetry method}

The optimum operational conditions for determination of bulk nitazoxanide applying linear sweep adsorptive cathodic stripping voltammetry (LS-AdCSV) at the HMDE in the B-R universal buffer of $\mathrm{pH} 4$ were identified. This was carried out by studying the effect of each of scan rate $v\left(20\right.$ to $\left.100 \mathrm{mV} \mathrm{s}^{-1}\right)$ and preconcentration potential $\mathrm{E}_{\text {acc. }}(+0.05$ to $-0.1 \mathrm{~V})$ on the peak current magnitude of $1 \times 10^{-7} \mathrm{~mol} \mathrm{~L}^{-1}$ bulk nitazoxanide. A better enhanced peak current magnitude was achieved at optimum operational conditions of scan rate $v=100 \mathrm{mV} \mathrm{s}^{-1}$, and $\mathrm{E}_{\text {acc }}=-0.05 \mathrm{~V}$ (vs. $\mathrm{Ag} / \mathrm{AgCl} / \mathrm{KCl}_{\mathrm{s}}$ ), Figure 3. On the other side, effect of preconcentration time $\left(\mathrm{t}_{\text {acc. }}\right)$ at $-0.05 \mathrm{~V}$ on the LS-AdCSV peak current magnitude of various concentrations of bulk nitazoxanide $\left(5 \times 10^{-7}, 1 \times 10^{-7}\right.$ and $\left.5 \times 10^{-8} \mathrm{~mol} \mathrm{~L}^{-1}\right)$ under the optimized operational conditions was evaluated. For $5 \times 10^{-7}$ and $1 \times 10^{-7} \mathrm{~mol} \mathrm{~L}^{-1}$ bulk nitazoxanide, the response was linear up to 60 and $120 \mathrm{~s}$, respectively, and then leveled off (Figure 4). This behavior may be attributed to the complete coverage of the mercury electrode surface with the analyte species. While for $5 \times 10^{-8} \mathrm{~mol} \mathrm{~L}^{-1}$ nitazoxanide, as the preconcentration time was increased, linearity was

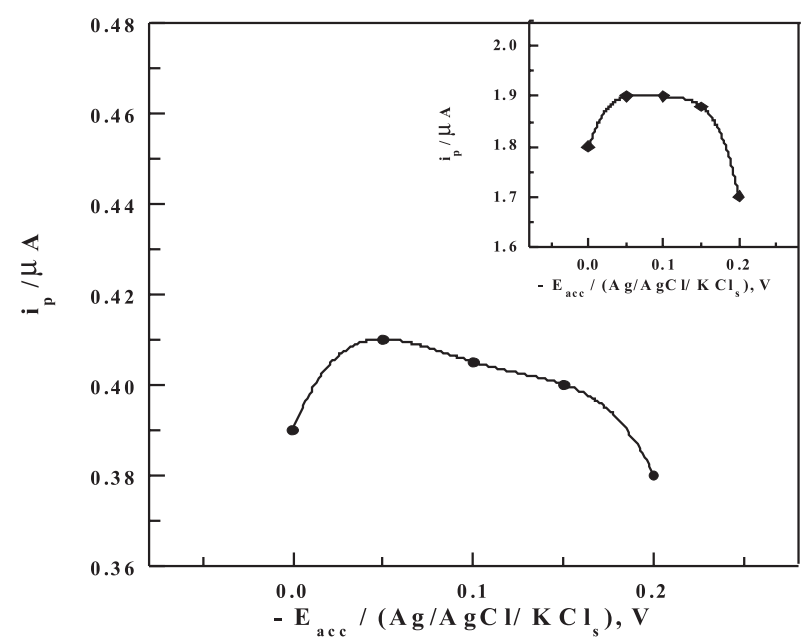

Figure 3. Plot of LS-AdCS voltammetry peak current $\left(\mathrm{i}_{\mathrm{p}}\right)$ vs. preconcentration potential $\left(\mathrm{E}_{\text {acc. }}\right.$ ) of $1 \times 10^{-7} \mathrm{~mol} \mathrm{~L}^{-1}$ bulk nitazoxanide following its preconcentration onto the HMDE for $30 \mathrm{~s}$ in the B-R universal buffer of $\mathrm{pH} 4$ at a scan rate of $100 \mathrm{mV} \mathrm{s}^{-1}$. Inset: The same study using SW-AdCSV; $\mathrm{f}=80 \mathrm{~Hz}, \mathrm{a}=25 \mathrm{mV}$ and $\Delta \mathrm{E}_{\mathrm{s}}=10 \mathrm{mV}$.

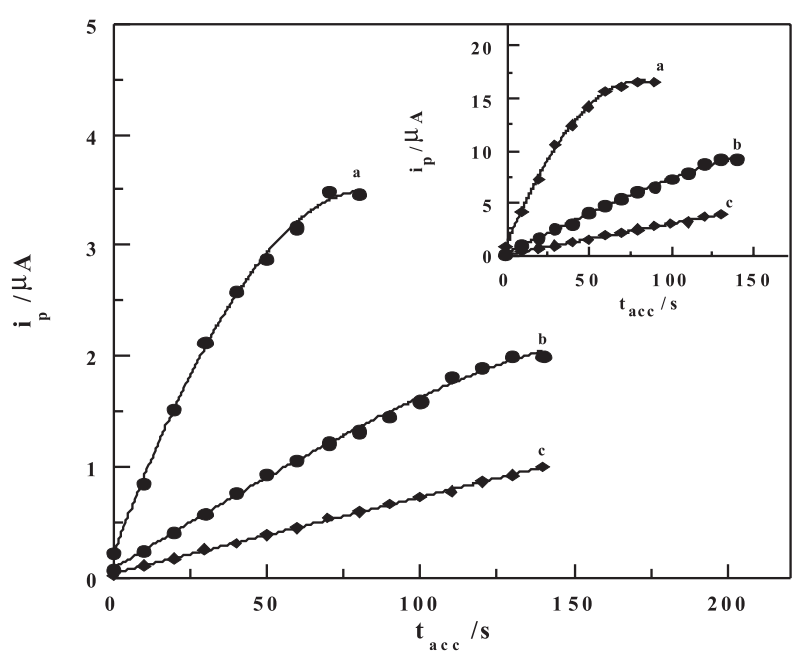

Figure 4. Plots of LS-AdCS voltammetry peak current ( $\left.\mathrm{i}_{\mathrm{p}}\right) v s$. preconcentration time $\left(\mathrm{t}_{\text {acc }}\right.$ ) of (a) $5 \times 10^{-7}$ (b) $1 \times 10^{-7}$ and (c) $5 \times 10^{-8} \mathrm{~mol} \mathrm{~L}^{-1}$ bulk nitazoxanide following preconcentration onto the HMDE at -0.05 $\mathrm{V}$ in the B-R universal buffer of $\mathrm{pH} 4$ at a scan rate of $100 \mathrm{mV} \mathrm{s}^{-1}$ Inset: The same study using SW-AdCS voltammetry; $\mathrm{f}=80 \mathrm{~Hz}, \mathrm{a}=25 \mathrm{mV}$ and $\Delta \mathrm{E}_{\mathrm{s}}=10 \mathrm{mV}$.

prevailed over the tested time. This means that the lower the concentration of the analyte, the longer of the accumulation time is. Therefore, $t_{\text {acc }} \leq 120$ was chosen in the rest of this study depending on the sensitivity needed.

LS-AdCS voltammograms of various concentrations of nitazoxanide were recorded under the optimized operational conditions and a linear variation of the peak current $\left(i_{p}\right)$ with concentration $(C)$ of bulk nitazoxanide was obtained within the concentration range of $5 \times 10^{-10}$ to $2 \times 10^{-7} \mathrm{~mol} \mathrm{~L}^{-1}$ bulk nitazoxanide following the regression equation: $\mathrm{i}_{\mathrm{p}}(\mu \mathrm{A})=57.5 \mathrm{C}\left(\mu \mathrm{mol} \mathrm{L} \mathrm{L}^{-1}\right)+0.085(\mathrm{r}=0.996$ and $n=17$ ). A limit of detection (LOD) of $1.5 \times 10^{-10} \mathrm{~mol} \mathrm{~L}^{-1}$ and a limit of quantitation (LOQ) of $5 \times 10^{-10} \mathrm{~mol} \mathrm{~L}^{-1}$ bulk nitazoxanide were estimated using the expression: k.S.D./ $b,{ }^{23}$ where $\mathrm{k}=3$ and 10 in case of LOD and LOQ, respectively. $\mathrm{SD}$ is the standard deviation of the intercept of calibration curves (or the blank) and b is the slope of the calibration curve.

\section{Differential pulse stripping voltammetry method}

The optimum operational conditions of pulse-height, scan rate and preconcentration parameters for determination of bulk nitazoxanide applying differential pulse adsorptive cathodic stripping voltammetry (DP-AdCSV) at the HMDE were identified. This was carried out by recording voltammograms of $5 \times 10^{-7} \mathrm{~mol} \mathrm{~L}^{-1}$ bulk nitazoxanide in the B-R universal buffer of $\mathrm{pH} 4$ under each of the following conditions: scan rate $\mathrm{v}\left(2\right.$ to $20 \mathrm{mV} \mathrm{s}^{-1}$ ), pulse height a ( 5 to $50 \mathrm{mV}$ ), preconcentration potential $\mathrm{E}_{\text {acc }}(+0.05$ to $-0.1 \mathrm{~V})$, and preconcentration time $\mathrm{t}_{\text {acc }}(0$ to $120 \mathrm{~s})$ for 
various concentrations of bulk nitazoxanide $\left(5 \times 10^{-7}, 1 \times 10^{-7}\right.$ and $\left.5 \times 10^{-8} \mathrm{~mol} \mathrm{~L}^{-1}\right)$. The results revealed that the optimal operational conditions which generated a well-shaped and a better enhanced current magnitude were found to be: $v=10 \mathrm{mV} \mathrm{s}^{-1}, \mathrm{a}=25 \mathrm{mV}, \mathrm{E}_{\text {acc }}=-0.05 \mathrm{~V}\left(v s . \mathrm{Ag} / \mathrm{AgCl} / \mathrm{KCl}_{\mathrm{s}}\right)$, and $t_{\text {acc }} \leq 120$ (depending on the sensitivity needed). DP-AdCS voltammograms of various concentrations of nitazoxanide were recorded under the optimal operational conditions and a linear variation of the peak current $\left(i_{p}\right)$ with concentration $(\mathrm{C})$ of bulk nitazoxanide was obtained within the concentration range of $8 \times 10^{-10}$ to $1 \times 10^{-7} \mathrm{~mol} \mathrm{~L}^{-1}$ following the regression equation: $\mathrm{i}_{\mathrm{p}}(\mu \mathrm{A})=46.6 \mathrm{C}(\mu \mathrm{M})+$ $0.3(r=0.995$ and $n=14)$. A LOD of $2.4 \times 10^{-10} \mathrm{~mol} \mathrm{~L}^{-1}$ and a LOQ of $8 \times 10^{-10} \mathrm{~mol} \mathrm{~L}^{-1}$ bulk nitazoxanide were achieved ${ }^{23}$ applying the described DP-AdCSV method.

\section{Square wave stripping voltammetry method}

Optimum operational conditions of both preconcentration and pulse-parameters for determination of bulk nitazoxanide applying square wave adsorptive cathodic stripping voltammetry (SW-AdCSV) were identified. This was curried out by studying the effect of changing of each of preconcentration potential $\mathrm{E}_{\mathrm{acc}}(0$ to $-0.2 \mathrm{~V})$, pulseheight a (5 to $50 \mathrm{mV})$, frequency $\mathrm{f}(10$ to $120 \mathrm{~Hz})$ and scan increment $\Delta \mathrm{E}$ ( 2 to $12 \mathrm{mV}$ ) on peak current magnitude of $1 \times 10^{-7} \mathrm{~mol} \mathrm{~L}^{-1}$ bulk nitazoxanide in the B-R universal buffer of $\mathrm{pH} 4$. The results revealed that the optimal operational conditions which generated a better enhanced current magnitude were: $\mathrm{E}_{\mathrm{acc}}=-0.05 \mathrm{~V}$ (vs. Ag/AgCl/KCl$)$ (Figure 3, Inset), $\mathrm{a}=25 \mathrm{mV}, \mathrm{f}=80 \mathrm{~Hz}$ and $\Delta \mathrm{E}_{\mathrm{s}}=10 \mathrm{mV}$. On the other side, effect of preconcentration time $\left(\mathrm{t}_{\text {acc. }}\right)$ at $-0.05 \mathrm{~V}$ on the SW-AdCS votammetric peak current magnitude of various concentrations of bulk nitazoxanide $\left(5 \times 10^{-7}, 1 \times 10^{-7}\right.$ and $\left.5 \times 10^{-8} \mathrm{~mol} \mathrm{~L}^{-1}\right)$ under the optimized operational conditions was evaluated (Figure 4 , Inset) and $\mathrm{t}_{\mathrm{acc}} \leq 120 \mathrm{~s}$ was chosen depending on the sensitivity needed.

SW-AdCS voltammograms of various concentrations of nitazoxanide were recorded under the optimal operational conditions and a linear variation of the peak current $\left(i_{p}\right)$ with concentration $(\mathrm{C})$ of bulk nitazoxanide was obtained within the concentration range of $1 \times 10^{-10}$ to $2 \times 10^{-7} \mathrm{~mol} \mathrm{~L}^{-1}$ following the regression equation: $i_{p}(\mu \mathrm{A})=76.36 \mathrm{C}(\mu \mathrm{M})+$ $0.176(r=0.998$ and $n=16)$. A LOD of $3 \times 10^{-11} \mathrm{~mol} \mathrm{~L}^{-1}$ and a LOQ of $1 \times 10^{-10} \mathrm{~mol} \mathrm{~L}^{-1}$ bulk nitazoxanide were achieved ${ }^{23}$ applying the described SW-AdCSV method.

\section{Methods validation}

Reproducibility, accuracy and precision ${ }^{24}$ of results applying the described stripping voltammetric methods were examined by performing four replicate analysis of standard solutions of bulk nitazoxanide over one day (intra-day assay) and for three successive days (inter-day assay), then calculating the mean percentage recovery $(\% \mathrm{R})$ for the found concentrations as a percent of the nominal concentrations in the standard solutions. Accuracy was expressed as relative error ( $\mathrm{RE} \%)$ while precision was assessed from the relative standard deviation in percentage ( $\mathrm{RSD} \%)$ of the mean recovery. The obtained results (Table 1) confirmed the reliability of the described stripping voltammetric methods for assay of nitazoxanide.

Effects of variation of some of the neck operational conditions such as $\mathrm{pH}$ (3.5 to 4.5$)$, preconcentration potential $(-0.05$ to $-0.1 \mathrm{~V})$ and preconcentration time (115 to $125 \mathrm{~s}$ ) on the peak current magnitude of nitazoxanide were also studied by means of the described stripping voltammetric methods. As shown in Table 2, as an example, the mean percentage recoveries of $5 \times 10^{-8} \mathrm{~mol} \mathrm{~L}^{-1}$ nitazoxanide based on four replicate measurements were insignificantly affected with variation of some of the neck operational conditions. Consequently the described stripping voltammetric methods are reliable for the assay of nitazoxanide and could be considered robust. ${ }^{24}$

The inter-laboratory precision ${ }^{24}$ of determination of $5 \times 10^{-8} \mathrm{~mol} \mathrm{~L}^{-1}$ bulk nitazoxanide was examined by the described stripping voltammetric methods using two different Models of PAR- Potentiostats 263A (Lab. 1) and 273-PAR (Lab. 2). The obtained results (e.g. Table 2) were found reproducible, since there was no significant difference in the mean percentage recoveries or the relative standard deviations. Thus the described stripping

Table 1. Analytical precision and accuracy of determination of $5 \times 10^{-8} \mathrm{~mol} \mathrm{~L}^{-1}$ bulk nitazoxanide by the described voltammetric methods in the B-R buffer of $\mathrm{pH} 4$ (number of replicated measurements $=4$ )

\begin{tabular}{|c|c|c|c|c|c|c|c|c|}
\hline \multirow[t]{2}{*}{ Method } & \multicolumn{4}{|c|}{ Intra-day } & \multicolumn{4}{|c|}{ Inter-day } \\
\hline & $\begin{array}{c}\text { [Found] } \\
\left(\mathrm{mol} \mathrm{L}^{-1}\right) \\
\end{array}$ & $\begin{array}{c}\text { Recovery } \\
\% \mathrm{R}\end{array}$ & $\begin{array}{c}\text { Accuracy } \\
\text { RE } \%\end{array}$ & $\begin{array}{c}\text { Precision } \\
\text { RSD \% }\end{array}$ & $\begin{array}{l}\text { [Found] } \\
\left(\mathrm{mol} \mathrm{L}^{-1}\right)\end{array}$ & $\begin{array}{c}\text { Recovery } \\
\% \mathrm{R}\end{array}$ & $\begin{array}{c}\text { Accuracy } \\
\text { RE } \%\end{array}$ & $\begin{array}{c}\text { Precision } \\
\text { RSD \% }\end{array}$ \\
\hline LS-AdCSV & $4.94 \times 10^{-8}$ & 98.8 & -1.20 & 2.30 & $4.91 \times 10^{-8}$ & 98.2 & -1.80 & 2.60 \\
\hline DP-AdCSV & $5.15 \times 10^{-8}$ & 103 & 3.00 & 0.40 & $4.89 \times 10^{-8}$ & 97.8 & -2.20 & 2.10 \\
\hline SW-AdCSV & $4.96 \times 10^{-8}$ & 99.2 & -0.80 & 1.00 & $4.93 \times 10^{-8}$ & 98.6 & -1.40 & 1.87 \\
\hline
\end{tabular}


Table 2. Validation studies for the direct determination of $5 \times 10^{-8} \mathrm{~mol} \mathrm{~L}^{-1}$ bulk nitazoxanide by means of the described SW-AdCS voltammetric method (number of replicated measurements $=4$ )

\begin{tabular}{lcc}
\hline Variables & $\begin{array}{c}\text { Operational } \\
\text { Conditions }\end{array}$ & $\% \mathrm{R} \pm \mathrm{RSD}$ \\
\hline $\mathrm{pH}$ of the medium & $\mathrm{E}_{\mathrm{acc}}=-0.05 \mathrm{~V}$ & $97.9 \pm 0.11$ \\
3.5 & $\mathrm{t}_{\mathrm{acc}}=120 \mathrm{~s}$ & $99.8 \pm 0.20$ \\
4.0 & & $98.2 \pm 0.33$ \\
4.5 & & \\
Preconcentration potential $\left(\mathrm{E}_{\mathrm{acc}}\right)$ & $\mathrm{pH}=4$ & $99.8 \pm 0.20$ \\
-0.05 & $\mathrm{t}_{\mathrm{acc}}=120 \mathrm{~s}$ & $97.8 \pm 0.25$ \\
-0.10 & & \\
Preconcentration time ( $\left.\mathrm{t}_{\mathrm{acc}}\right)$ & $\mathrm{pH}=4$ & $97.8 \pm 0.25$ \\
115 & $\mathrm{E}_{\mathrm{acc}}=-0.05 \mathrm{~V}$ & $99.8 \pm 0.20$ \\
120 & & $98.2 \pm 0.85$ \\
125 & & \\
Inter-laboratory precision & & $99.8 \pm 0.20$ \\
Lab (1) & $\mathrm{pH}=4$ \\
Lab (2) & $\mathrm{E}_{\mathrm{acc}}=-0.05 \mathrm{~V}$ & $97.5 \pm 0.87$ \\
& $\mathrm{t}_{\mathrm{acc}}=120 \mathrm{~s}$ & \\
\hline
\end{tabular}

voltammetric methods are reliable for assay of nitazoxanide and could be considered rugged. ${ }^{24}$

Selectivity ${ }^{24}$ can be described as the capability of the method to accurately measure the response of the analyzed compound with no interferences originating from sample matrix. Here the selectivity ${ }^{24}$ of the described stripping voltammetric methods was tested by analysis of different standard solutions of bulk nitazoxanide in the absence and the presence of the common excipients such as lactose, starch, gelatin, talc and magnesium trisilicate. Statistically, insignificant differences between mean recoveries in the absence of excipients $(99.56 \pm 0.88,98.16 \pm 1.24$, and 99.62 $\pm 0.94)$ and in their presence $(98 \pm 0.38,101 \pm 1.16$, and $99.3 \pm 0.84$ ) for analysis of $1 \times 10^{-8} \mathrm{~mol} \mathrm{~L}^{-1}$ bulk nitazoxanide were obtained by mean of the described LS-AdCSV, DPAdCSV and SW-AdCSV methods, respectively.

\section{Stability indicating property}

According to the International Conference on Harmonization ( $\mathrm{ICH}$ ) guidelines ${ }^{25}$ it was thought necessary to study stability of the described stripping voltammetric method for determination of nitazoxanide in the presence of its degradation products. This was carried out by recording SW-AdCS voltammograms of $1 \times 10^{-7} \mathrm{~mol} \mathrm{~L}^{-1}$ nitazoxanide solution after subjected to induced degradation with $2.0 \mathrm{~mol} \mathrm{~L}^{-1} \mathrm{HCl}$ (as described in the experimental section) under the optimum operational conditions. The recorded voltammograms exhibited a significant decay of the peak current of nitazoxanide with time until it disappeared completely, while no any other voltammetric peak appeared (Figure 5, curves b-f). This behavior indicated

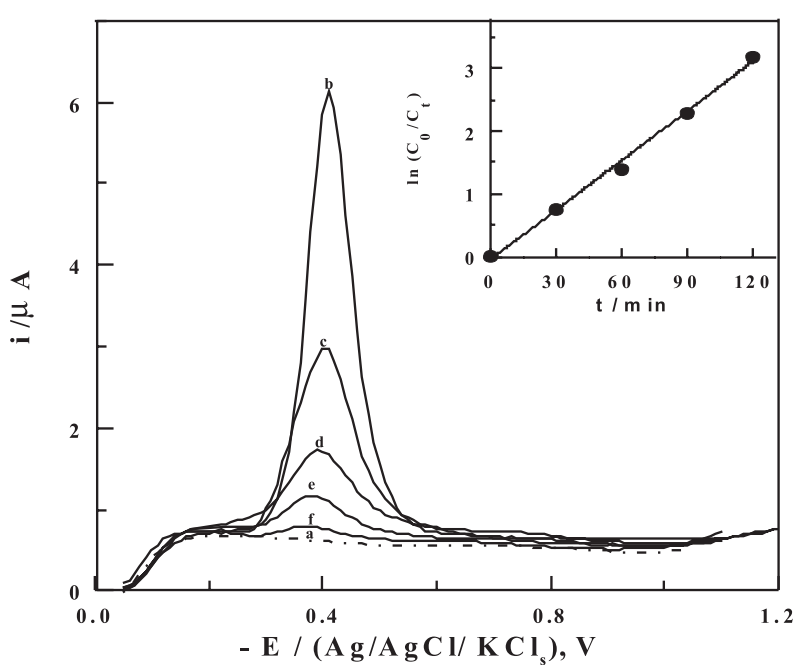

Figure 5. SW-AdCS voltammograms of $1 \times 10^{-7} \mathrm{~mol} \mathrm{~L}^{-1}$ nitazoxanide solution in the B-R universal buffer of $\mathrm{pH} 4$ : Background (a), before treatment with $\mathrm{HCl}$ (b), then after induced degradation with $2.0 \mathrm{~mol} \mathrm{~L}^{-1}$ $\mathrm{HCl}$ for different time intervals $t$ (min): 30 (c), 60 (d), 90 (e), and 120 (f); $\left\{\mathrm{f}=80 \mathrm{~Hz} ; \mathrm{a}=25 \mathrm{mV}\right.$ and $\left.\Delta \mathrm{E}_{\mathrm{s}}=10 \mathrm{mV}\right\}$. Inset: plot of $\ln \left(\mathrm{C}_{\mathrm{o}} / \mathrm{C}_{\mathrm{t}}\right)$ vs. time $\mathrm{t}(\mathrm{min})$.

the complete degradation of nitazoxanide in acid medium and that the degradation product is electro-inactive under the experimental conditions. On the other side, SW-AdCS voltammograms of a solution of $5 \times 10^{-8} \mathrm{~mol} \mathrm{~L}^{-1}$ bulk nitazoxanide, in the absence and the presence of an acid-induced degraded solution of $1 \times 10^{-7} \mathrm{~mol} \mathrm{~L}^{-1}$ nitazoxanide were recorded under the optimum operational conditions. Results of analysis revealed that there is no significant interference from the degradation products since insignificance difference was observed in the mean percentage recoveries and relative standard deviations in the absence $(99.94 \pm 0.68)$ and the presence $(98.0 \pm 1.57)$ of the degradation product.

Degradation rate constant and half-life were computed from slope of the $\ln \left(\mathrm{C}_{\mathrm{o}} / \mathrm{C}_{\mathrm{t}}\right)$ vs. time $(\mathrm{t})$ plot $\left(\mathrm{C}_{\mathrm{o}}\right.$ is the initial concentration of the nitazoxanide and $\mathrm{C}_{t}$ its concentration during the acid-induced degradation reaction for the time interval $t$ ). Decay of concentration $\left(C_{t}\right)$ of nitazoxanide during acid-induced degradation reaction with time $(\mathrm{t})$ is exponential and the linear-fit relationship between $\ln$ $\left(\mathrm{C}_{\mathrm{o}} / \mathrm{C}_{\mathrm{t}}\right)$ and time $(\mathrm{t})$ up to $120 \mathrm{~min}$ (Figure 5, inset) indicating that the acid induced degradation of nitazoxanide follows pseudo first-order kinetics. The apparent degradation rate constant $(\mathrm{k})$ and half-life $\left(\mathrm{t}_{1 / 2}\right)$ were estimated and found to be $2.1 \times 10^{-2} \mathrm{~min}^{-1}$ and $33.9 \mathrm{~min}$, respectively.

Moreover, stripping voltammetric determination of nitazoxanide in the presence of its base-induced degradation products (as described in the experimental section) was carried out under the optimum operational conditions. SW-AdCS voltammogram of $1 \times 10^{-7} \mathrm{~mol} \mathrm{~L}^{-1}$ nitazoxanide solution subjected to base-induced degradation with 
$0.5 \mathrm{~mol} \mathrm{~L}^{-1} \mathrm{NaOH}$ at room temperature exhibited very fast decay of the cathodic peak current of nitazoxanide $\left(E_{p}=-0.4 \mathrm{~V}\right)$ for $5 \mathrm{~min}$ of treatment, with the appearance of a new cathodic peak at more negative potential, $\mathrm{E}_{\mathrm{p}}=-0.62 \mathrm{~V}$, (Figure 6, curve b), compared with that of the untreated nitazoxanide solution (Figure 6, curve a). This behavior indicated the extensive base-induced degradation of nitazoxanide with the formation of an electroactive product $\left(E_{p}=-0.62 \mathrm{~V}\right)$. However, the peak current magnitude of the new peak ( $2^{\text {nd }}$ peak) decreased with progressing time of degradation (Figure 6, curves b-d) which may be due to further hydrolysis of the degradation product to an electroinactive one. As shown in inset of Figure 6, the height of the cathodic peak ( $1^{\text {st }}$ peak) of $1 \times 10^{-7} \mathrm{~mol} \mathrm{~L}^{-1}$ nitazoxanide solution which was subjected to base-induced degradation for 5 min (curve b) was increased upon the addition of a standard solution of $5 \times 10^{-8} \mathrm{~mol} \mathrm{~L}^{-1}$ bulk nitazoxanide (curve e) while that of the $2^{\text {nd }}$ peak is not. This behavior indicated that the latter is due to reduction of the degradation product. A mean percentage recovery of the added nitazoxanide was found to be $101.05 \pm 1.42$ indicating the successful assay of nitazoxanide without interference from its base-induced degradation product. Therefore, the described methods can be consider specific and could be used successfully as stability-indicating methods for assay of nitazoxanide. However, fast degradation of nitazoxanide with $\mathrm{NaOH}$ does not allow the study of kinetics of its degradation reaction. A suggested acid and base-induced degradation reaction of nitazoxanide is shown in Scheme B.

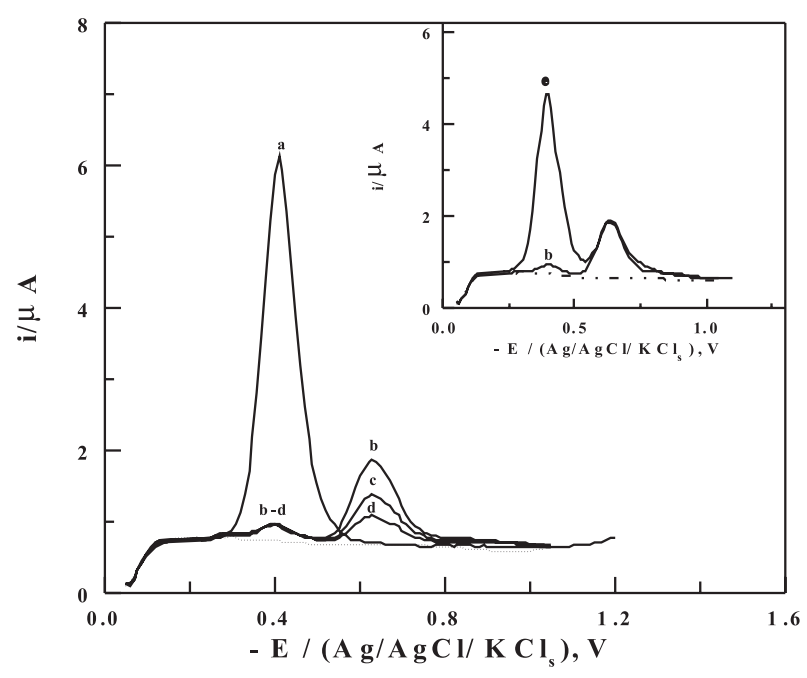

Figure 6. SW-AdCS voltammograms of $1 \times 10^{-7} \mathrm{~mol} \mathrm{~L}^{-1}$ nitazoxanide in the B-R universal buffer of $\mathrm{pH}$ 4: before treatment with $\mathrm{NaOH}(\mathrm{a})$, then during induced degradation with $0.5 \mathrm{~mol} \mathrm{~L}^{-1} \mathrm{NaOH}$ for different time intervals t ( $\mathrm{min}$ ): 5 (b), 15 (c), and 25 (d). Inset: after induced degradation with $0.5 \mathrm{~mol} \mathrm{~L}^{-1} \mathrm{NaOH}$ for $5 \mathrm{~min}(\mathrm{~b})$ and the same solution after addition of $5 \times 10^{-8} \mathrm{~mol} \mathrm{~L}^{-1}$ bulk nitazoxanide (e) Dotted line represents background; $\mathrm{f}=80 \mathrm{~Hz} ; \mathrm{a}=25 \mathrm{mV}$ and $\Delta \mathrm{E}_{\mathrm{s}}=10 \mathrm{mV}$.

AM1 semi-empirical molecular orbital energy calculations of the bond orders throughout the nitazoxanide molecule revealed that the weakest bond orders within nitazoxanide molecule (I) are the $\mathrm{C}-\mathrm{O}$ bond of the acetate group (0.9616) and the $\mathrm{C}_{5}-\mathrm{NO}_{2}$ bond (0.9066) of thiazol ring. Based on these data, the acid-induced degradation of nitazoxanide may be attributed to hydrolysis of the ester group of phenyl ring ${ }^{26-28}$ and cleavage of nitro group of<smiles>CC(=O)Oc1ccccc1C(=O)Nc1ncc([N+](=O)[O-])s1</smiles>

(I)
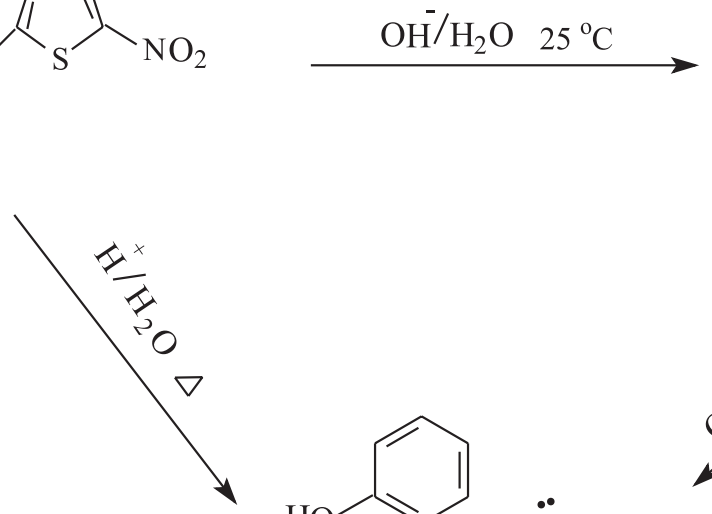<smiles>O=C(Nc1nccs1)c1ccccc1O</smiles>

(III)<smiles></smiles>

(II) 
thiazol ring leading to formation of the electro-inactive product (III). This is consistent with the decay of the mean cathodic peak of nitazoxanide without the appearance of any additional cathodic peak (Figure 5). While, the baseinduced degradation of nitazoxanide may lead first to formation of the electro-active yellow anionic intermediate (II) by deprotonation of the 2-amino group of thiazol ring ${ }^{29}$ and hydrolysis of the ester group of the phenyl ring ${ }^{26-28}$ then losing the nitro group of the thiazol ring ${ }^{30}$ to form the protonated neutral colorless electro-inactive product (III) due to loss of resonance in the thiazole ring. ${ }^{29,31}$ This is consistent with the practically disappearance of main cathodic peak of nitazoxanide and appearance of a new peak, $\mathrm{E}_{\mathrm{p}}=-0.62 \mathrm{~V}$, (Figure 6, curves b-d) corresponding to reduction of the nitro group of the anionic intermediate product (II) at more negative potential compared to that of standard nitazoxanide (due to the condensed electron density on thiazole ring due to resonance). ${ }^{29,31}$ Moreover, decay of $2^{\text {nd }}$ peak current of the degraded product (II) with progressing time of degradation reaction confirms further hydrolysis of product (II) to the electro-inactive product (III). The negative azo-test for degraded nitazoxanide solution indicated that molecules of the degradation product are free from free primary amino groups which mean that cleavage of amide bond or reduction of $\mathrm{NO}_{2}$ to amine stage are not involved in the hydrolysis process of nitazoxanide. Besides, UV-visible absorption spectrum of $2 \times 10^{-5} \mathrm{~mol} \mathrm{~L}^{-1}$ nitazoxanide (I) recorded in the B-R universal buffer of $\mathrm{pH} 7$ exhibited an absorbance band at $420 \mathrm{~nm}^{29}$ (Figure 7) which decays over the time of acid or base induced degradation reaction due to the loss of $\mathrm{NO}_{2}$ group with the appearance of a new absorbance band at ca. $288 \mathrm{~nm}$ which may be due to the formation of de-nitroderivative (III). ${ }^{29-31}$

\section{Applications}

Assay of nitazoxanide in "Cryptonaz powder"

The described stripping voltammetric methods (LS-AdCSV, DP-AdCSV and SW-AdCSV) were

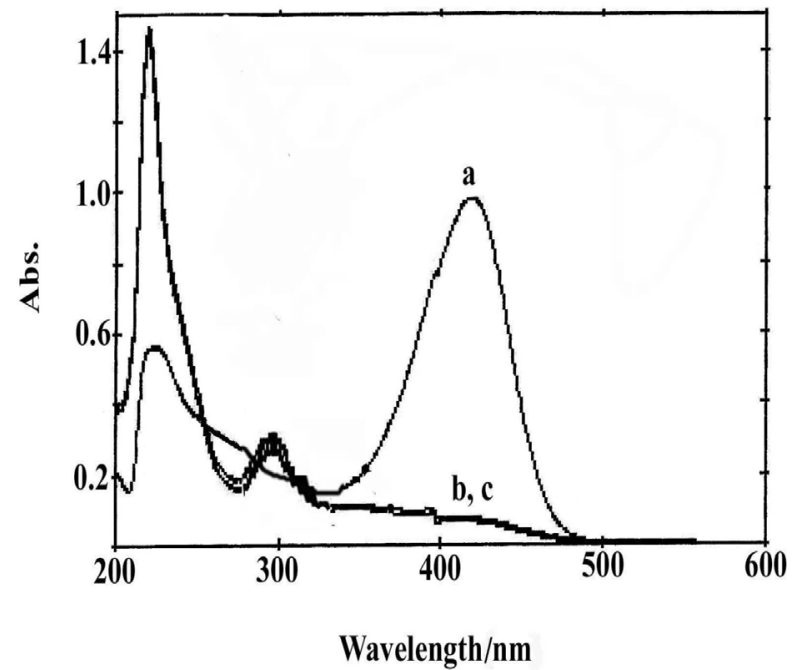

Figure 7. UV-visible electronic absorption spectra of $2.0 \times 10^{-5} \mathrm{~mol} \mathrm{~L}^{-1}$ nitazoxanide in the B-R universal buffer of $\mathrm{pH} 7$ containing 20\% (v/v) acetonitrile: before treatment with $\mathrm{NaOH}$ (a), then during induced degradation with $0.5 \mathrm{~mol} \mathrm{~L}^{-1} \mathrm{NaOH}$ for different time intervals $\mathrm{t}$ (min): 5 (b) and 25 (c).

successfully applied to determination of nitazoxanide in its pharmaceutical formulation (Cryptonaz powder) without the necessity for samples pretreatment, time-consuming extraction steps or formation of colored chromogens prior to the analysis. The results indicated insignificant differences between the taken and found concentrations and consequently between mean percentage recoveries based on four replicate measurements (Table 3). The satisfactory results obtained by means of the described stripping voltammetric methods using both the calibration curve and standard addition methods (Table 3) were statistically compared with those obtained by a reported RP-LC method. ${ }^{8}$ The calculated F-values did not exceed the theoretical ones (Table 3), which means that there is no significant difference between the described stripping voltammetric and the reported RP-LC ${ }^{8}$ methods with respect to reproducibility. ${ }^{32}$ Also, no significant differences were noticed between the described and reported methods regarding the accuracy and precision as revealed by t-test. ${ }^{32}$

Table 3. Assay of nitazoxanide in its formulation (Cryptonaz powder) by means of the described stripping voltammetric and a reported reverse phase liquid chromatography (RP-LC) $)^{8}$ methods

\begin{tabular}{lcccc}
\hline Described method & \multicolumn{2}{c}{$(\% \mathrm{R} \pm \mathrm{RSD})$} & \multicolumn{2}{c}{ F-value and t-test } \\
\cline { 2 - 5 } & $(\mathrm{A})$ & $(\mathrm{B})$ & (A) & 1.67 and 2.40 \\
\hline LS-AdCSV & $98.63 \pm 2.33$ & $99.7 \pm 1.65$ & 1.96 and 1.59 & 1.19 and 1.95 \\
DP-AdCSV & $99.0 \pm 2.52$ & $99.0 \pm 1.48$ & 2.15 and 1.24 & 1.14 and 0.44 \\
SW-AdCSV & $99.58 \pm 1.23$ & $99.74 \pm 1.50$ & & \\
RP-LC & $100.4 \pm 1.80$ & & &
\end{tabular}

(A) Using the calibration curve method and (B) Using the standard addition method. The theoretical values of $\mathrm{F}$ and $\mathrm{t}$-test at $95 \%$ confidence limit for $\mathrm{n}_{1}$ $=4$ and $\mathrm{n}_{2}=4$ ( $\mathrm{n}=$ Number of replicated measurements $)$ are 9.28 and 2.78 , respectively. 


\section{Assay of nitazoxanide in spiked human serum}

Nitazoxanide spiked in human serum was successfully analyzed by the described voltammetric methods (LS-AdCSV, DP-AdCSV and SW-AdCSV) without the necessity for extraction of the drug prior to the analysis. Representative SW-AdCS voltammograms of nitazoxanide spiked in human serum recorded under the optimum operational conditions of the described stripping voltammetric methods are shown in Figure 8. As shown in Figure 8 (curve a), no interfering peaks were observed in the blank human serum within the studied potential range. Linear variations of the peak current $\left(i_{p}\right)$ with concentration of nitazoxanide spiked in human serum were obtained within the concentration ranges of $3 \times 10^{-9}$ to $2 \times 10^{-7} \mathrm{~mol} \mathrm{~L}^{-1}$ (LS-AdCSV), $5 \times 10^{-9}$ to $1 \times 10^{-7} \mathrm{~mol} \mathrm{~L}^{-1}$ (DP-AdCSV) and $1 \times 10^{-9}$ to $1 \times 10^{-7} \mathrm{~mol} \mathrm{~L}^{-1}(\mathrm{SW}-\mathrm{AdCSV}$ ) following the regression equations: $\left(i_{p}(\mu \mathrm{A})=45.14 \mathrm{C}\left(\mu \mathrm{mol} \mathrm{L}{ }^{-1}\right)+0.31\right.$; $\mathrm{r}=0.985$ and $\mathrm{n}=12),\left(\mathrm{i}_{\mathrm{p}}(\mu \mathrm{A})=41.80 \mathrm{C}\left(\mu \mathrm{mol} \mathrm{L}{ }^{-1}\right)+0.466\right.$; $\mathrm{r}=0.990$ and $\mathrm{n}=11)$, and $\left(\mathrm{i}_{\mathrm{p}}(\mu \mathrm{A})=55.5 \mathrm{C}\left(\mu \mathrm{mol} \mathrm{L}{ }^{-1}\right)+\right.$ $0.169 ; r=0.999$ and $n=12)$, respectively. Detection limits of $9 \times 10^{-10}, 1.5 \times 10^{-9}$ and $3 \times 10^{-10} \mathrm{~mol} \mathrm{~L}^{-1}$ and quantitation limits of $3 \times 10^{-9}, 5 \times 10^{-9}$ and $1 \times 10^{-9} \mathrm{~mol} \mathrm{~L}^{-1}$ nitazoxanide were achieved by the described LS-AdCSV, DP-AdCSV and SW-AdCSV methods, respectively. Mean percentage recoveries and relative standard deviations of $98.2 \pm 0.55$ (LS-ADCSV), $97.8 \pm 0.45$ (DP-AdCSV) and $98.5 \pm 0.3$ (SW-AdCSV) were achieved based on four replicate measurements of $5 \times 10^{-8}$ mol L-1 nitazoxanide spiked in human serum. These results confirmed the reliability of the described stripping voltammetric methods for assay of nitazoxanide in human serum.

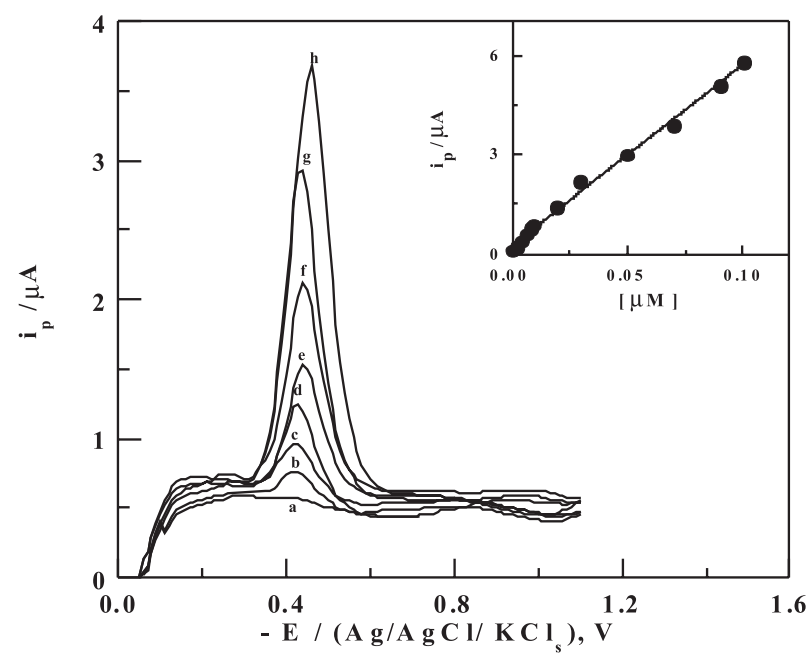

Figure 8. SW-AdCS voltammograms of various concentrations of nitazoxanide spiked in human serum: (a) Background, (b) $1 \times 10^{-9}$, (c) $3 \times 10^{-9}$, (d) $7 \times 10^{-9}$, (e) $1 \times 10^{-8}$, (f) $2 \times 10^{-8}$, (g) $3 \times 10^{-8}$ and (h) $5 \times 10^{-8} \mathrm{~mol} \mathrm{~L}^{-1}$ following preconcentration onto the HMDE at $\mathrm{E}_{\text {acc }}=-0.05 \mathrm{~V}$ for $120 \mathrm{~s}$ in the B-R universal buffer of $\mathrm{pH} 4 ; \mathrm{f}=80 \mathrm{~Hz} ; \mathrm{a}=25 \mathrm{mV}$ and $\Delta \mathrm{E}=10 \mathrm{mV}$

\section{Conclusions}

The electro-reduction of nitazoxanide at the HMDE in buffered solution was studied and discussed. Based on the adsorption behavior of nitazoxanide onto the mercury electrode surface, simple and highly sensitive linear sweep, differential pulse and square wave adsorptive cathodic stripping voltammetric methods were developed for determination of nitazoxanide in bulk form, formulation "Cryptonaz powder" and in spiked human serum without the necessity for extraction ${ }^{4-10}$ or formation of colored chromogens ${ }^{11-13}$ prior to analysis. Nitazoxanide was also analyzed successfully without interferences from excipients or from its acid or base-induced degradation products. The achieved limits of quantitation (LOQ) by means of the described stripping voltammetric methods are low as well as they offer good possibilities for determination of drug in low-dosage pharmaceutical preparations and in real plasma samples. The described methods could be recommended for use in quality control and clinical laboratories.

\section{Acknowledgements}

M.M. Ghoneim expresses his gratitude to the Alexander von Humboldt Foundation (Bonn, Germany) for donating the Electrochemical Analyzer (263A-PAR) and the personal computer used in the present study.

\section{References}

1. Sweetman, S. C.; Martindale The Complete Drug Reference, $33^{\text {rd }}$ ed., London: The Pharmaceutical Press, 2002.

2. O'Neil, M. J.; The Merck Index, $13^{\text {th }}$ ed., Merck \& Co., Inc.: Whitehouse Station: New Jersey, 2001.

3. Stockis, A.; Deroubaix, X.; Lins, R.; Jeanbaptiste, B.; Calderon, P.; Rossignol, J. F.; Int. J. Clin. Pharmacol. Ther. 1996, 34, 349.

4. Rane, V. P.; Sangshetti, J. N.; Patil, K. R.; Yeole, R. D.; Shinde, D. B.; Chromatographia 2008, 67, 455.

5. Jadhav, A. S.; Pathare, D. B.; Shingare, M. S.; Chromatographia 2007, 66, 595 .

6. Lin, X.-L.; Liang, G.-D.; Xia, Z.-N.; Chin. J. Pharm. Anal. 2004, 24, 247.

7. Gopu, C. L.; Thomas, S.; Paradkar, A. R.; Mahadik, K. R.; J. Sci. Ind. Res. 2007, 66, 141.

8. Malesuik, M. D.; Cardoso, S. G.; Steppe, M.; Chromatographia 2008, 67, 131.

9. Kalta, R. R.; Sharma, R.; Chaturvedi, S. C.; Indian J. Pharm. Sci. 2008, 70, 491 .

10. Sakamoto, T.; Hiyama, Y.; Pharmazie 2008, 63, 503.

11. Lakshminarayana, K. V.; Manohara, Y. N.; Gurupadayya, B. M.; Indian J. Pharm. Sci. 2007, 69, 147. 
12. Kapse, G. K.; Prabhakar, G.; Appala, R. S.; Indian J. Pharm. Sci. 2007, 68, 403 .

13. Narayana, K. V. L.; Manohara, Y. N.; Asian J. Chem. 2007, 19, 2527.

14. Wang, J.; Analytical Electrochemistry, $2^{\text {nd }}$ ed., Wiley-VCH: New York, 2000.

15. Jain, R.; Dwivedi, A.; Mishra, R.; J. Hazard. Mater. 2009, 169, 667.

16. Zuman, P.; Collect. Czech. Chem. Commun. 1993, 58, 41.

17. Melo, A. M. Dos S.; Valentim, I. B.; Goulart, M. O. F.; De Abreu, F. C.; J. Braz. Chem. Soc. 2008, 19, 704.

18. Zuman, P.; The Elucidation of Organic Electrode Processes, Academic Press: New York, 1969.

19. Ghoneim, M. M.; El-Ries, M.; Hassanein, A. M.; Abd-Elaziz, A. M.; J. Pharm. Biomed. Anal. 2006, 41, 1268.

20. Nicholson, R. S.; Shain, I.; Anal. Chem. 1964, 36, 706.

21. Greef, R.; Peat, R.; Plter, I. M.; Pletcher, D.; Robinson, J.; Instrumental Methods of analysis in Electrochemistry, E. Horwood, Chichester, 1985.

22. Laviron, E.; Roullier, L.; Degrand, C. A.; J. Electroanal. Chem. 1980, 112, 11 .

23. Miller, J. C.; Miller, J. N.; Statistics for Analytical Chemistry, $3^{\text {rd }}$ ed., Ellis Harwood Series, Prentice Hall: New York, 1993.

24. United States Pharmacopoeia Convention, The United States Pharmacopoeia: The National Formulary, $26^{\text {th }}$ ed., Convention Inc., 2003.
25. ICH, Proceedings of the International Conference on Harmonization, ICH Q1A, Stability Testing of New Drug Substances and Products, Geneva, 1993.

26. Harris, J.; Wamser, C.; Fundamentals of Organic Reaction Mechanisms, Wiley: New York, 1976.

27. McMurry, J.; Castellion, M. E.; Ballantine, D. S.; Fundamentals of General, Organic, and Biological Chemistry, $5^{\text {th }}$ ed., Prentice Hall, 2007.

28. Clayden, J.; Greeves, N.; Warren, S.; Wothers, P.; Organic Chemistry, Oxford University Press: Oxford, 2001.

29. Hoffman, P. S.; Sisson, G.; Croxen, M. A.; Welch, K.; Harman, W. D.; Cremades, N.; Morash, M. G.; Antimicrob. Agents Chemother. 2007, 51, 868.

30. Trukhacheva, L. A.; Levina, V. I.; Grigor'ev, N. B.; Arzamastsev, A. P.; Dalinger, I.; Vatsadze, I. A.; Popova, G. P.; Shevelev, S. A.; Granikb, V. G.; Russ. Chem. Bull. 2005, 54, 2813.

31. Pankuch, G. A.; Appelbaum, P. C.; Antimicrob. Agents Chemother. 2006, 50, 1112.

32. Christian, G. D.; Analytical Chemistry, $5^{\text {th }}$ ed., John Wiley \& Sons Inc.: USA, 1994.

Received: June 21, 2009

Web Release Date: December 21, 2009 